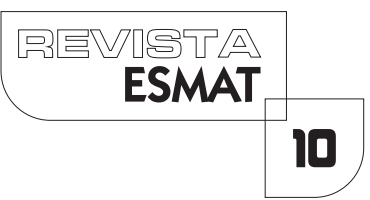

\title{
A EFICÁCIA DO CONTROLE DE CONSTITUCIONALIDADE EXERCIDO PELO TRIBUNAL DE CONTAS DO ESTADO DO TOCANTINS
}

Luanna Mannaia Costa Lopes

Graduada na Faculdade Católica do Tocantins (FACTO). Pós graduando em Direito Processual Civil pela Instituição de Ensino Damásio. Advogada. Email: luannamannaia@gmail.com.

Lara Lívia Cardoso Costa Bringel

Graduação em Direito na Universidade de Marília, UNIMAR. Especialização em Direito do Estado. Mestrado em Direto, Relações Internacionais e Desenvolvimento, na Pontifícia Universidade Católica de Goiás, PUC GOIÁS. laralíviacardoso@hotmail.com.

\section{RESUMO}

O presente trabalho tem por finalidade analisar a eficácia da atuação dos Tribunais de Contas, em especial o Tribunal de Contas do Estado do Tocantins, no que tange ao Controle de Constitucionalidade Difuso. Será demonstrada a influência que as Cortes de Contas acarretam ao realizar o controle, partindo da ideia de um Estado Democrático de Direito. A fiscalização das verbas públicas se mostra imprescindível ao longo da história do Brasil, e a atuação comedida, porém imparcial, dos Tribunais de Contas no âmbito jurisdicional acarreta segurança jurídica aos cidadãos, por evitar o descontrole de gastos por parte da Administração, além de contribuir efetivamente para a Separação dos Poderes, princípio constitucional fundamental.

PALAVRAS-CHAVE: Administração pública; Controle de Constitucionalidade; Erário; Tribunal de Contas.

\section{ABSTRACT}

This study aims to analyze the effectiveness of the performance of the Audit Courts, in particular the Court of the State of Tocantins, in regard to the Constitutional Fuzzy Control. It will be shown to influence the accounts of Cortes carry when performing 
control, based on the idea of a democratic state. The oversight of public funds proves essential throughout the history of Brazil, measured performance, however impartial, Audit Courts in the judicial context brings legal certainty for citizens, to avoid uncontrolled spending by the administration, and effectively contributes for the separation of powers, fundamental characteristic of a democratic state.

KEYWORDS: Public Administration; Constitutionality control; treasury; Audit Office.

\section{INTRODUÇÃO}

Ao longo da história ocidental, é notória a necessidade de fiscalização sobre os administradores públicos, no que tange ao erário -, proveniente das contribuições individuais de recursos do próprio Estado. De igual modo, hoje, em pleno século XXI, esse procedimento é indispensável para a segurança dos cidadãos, de forma geral.

A preocupação com a destinação das verbas públicas no Brasil é caótica diante de inúmeros gastos injustos e desnecessários por parte da Administração, os quais desmotivam o cidadão trabalhador. Diariamente, imprensa, julgamentos judiciais e pesquisas mostram o quanto o povo brasileiro é omisso quanto à prestação de contas dos bens e recursos públicos, que, em tese, teriam a função de servir a população com eficiência e desenvoltura, características típicas dos países de maior referência no mundo.

A moral e a probidade são princípios consagrados na atual Constituição Federal, de 1988, que mostrou grande interesse na proteção destes, especialmente na seara das consequências dos atos de improbidade administrativa. Ademais, a regulamentação aos atos de improbidade revela a preocupação do constituinte para com a proteção do patrimônio público.

Os Tribunais de Contas do Brasil atuam de forma imprescindível para o adequado exercício da cidadania e concretização do Estado Democrático de Direito. Esse perfil de organização estatal decorre de extenso processo da evolução de organização das sociedades, e as principais características são: lei imposta a todos, separação dos poderes estatais e prevalência dos direitos fundamentais.

Dessarte, tais Cortes são órgãos de natureza técnica que auxiliam o Poder Legislativo no controle e fiscalização contábil, financeira, operacional, orçamentária e patrimonial de cada entidade federada e suas respectivas administrações.

Ademais, são autônomos e independentes, haja vista gozarem das mesmas garantias institucionais destinadas ao Poder Judiciário. Contudo, há certa peculiaridade à luz do entendimento do Supremo Tribunal Federal, a qual versa sobre o poder concedido aos 
Tribunais de Contas, qual seja, apreciar a constitucionalidade das leis e dos atos do Poder Público, no exercício de suas competências.

Em regra, o controle de constitucionalidade é jurisdicional, ou seja, exercido pelo Poder Judiciário. No entanto, o poder executivo ou o legislativo podem exercê-lo. Trata-se exatamente do Princípio da Separação de Poderes, aplicável no âmbito do controle de constitucionalidade.

Evidentemente, os fundamentos que contribuem para a concretização do sistema desse controle, realizado por diversos órgãos, surgem de modo a resguardar as diversas normas que compõem o Ordenamento Jurídico Brasileiro, garantindo-Ihe autonomia e segurança jurídica.

Dessa forma, o controle realizado pelos Tribunais de Contas possui uma função precisa e adequada, contribuindo para o bom funcionamento do Estado Democrático de Direito, em que as próprias autoridades políticas devem respeitar as regras de direito, como cidadãos.

A pesquisa consiste, portanto, em verificar se os Tribunais de Contas possuem o condão de exercer o controle de constitucionalidade difuso e, consequentemente, se é válida e eficaz a Súmula 347, proferida anteriormente à nova Constituição, pelo Supremo Tribunal Federal, que trata sobre o poder atribuído aos Tribunais de Contas, isto é, analisar a Constitucionalidade de leis e atos normativos.

\section{CONTROLE DE CONSTITUCIONALIDADE}

Em nosso ordenamento jurídico é adotada uma Constituição escrita do tipo rígida, cuja alteração exige um procedimento especial, ainda mais complexo em relação à produção das demais leis, até mesmo as ordinárias. Isso ocorre devido ao princípio da supremacia formal, típico dos sistemas jurídicos que adotam a Constituição como rígida, de modo que suas normas são supremas, isto é, são hierarquicamente superiores a todas as outras manifestações de direito.

Desse modo, essa Lei Magna torna-se parâmetro para a elaboração de todos os demais atos normativos estatais, os quais devem respeitar os princípios e regras nela previstos, de forma que mantenham o status de norma constitucional, sob pena de se incorrer em insanável vício de inconstitucionalidade. Havendo confronto entre o texto constitucional e uma norma inferior, deverá ser declarada a nulidade desta em respeito à supremacia da Constituição.

É de extrema importância destacar outro fator relevante decorrente desse princípio da supremacia constitucional: a necessidade de separação de poderes e, em consequência, a concretização do Estado de Direito. Necessita-se, pois, de pelo menos um órgão estatal, independente daquele responsável pela elaboração das leis, em que a Constituição atribua competência para verificação da conformidade das demais normas com seus princípios e regras. 
As leis e atos normativos são protegidos pelo princípio da presunção de constitucionalidade das leis, isso significa que os dispositivos legais de nosso ordenamento devem ser considerados constitucionais, válidos e legítimos até que venham a ser formalmente declarados inconstitucionais por um órgão competente para tal. Enquanto não formalmente reconhecidos como inconstitucionais, deverão ser cumpridos pela cidadania brasileira. Esse reconhecimento é medida excepcional e, portanto, a inconstitucionalidade somente poderá ser proclamada por um órgão que goze de competência constitucional para tanto.

Os renomados autores Marcelo Alexandrino e Vicente Paulo definem como inconstitucional a ação ou omissão que ofende, no todo ou em parte, a Constituição. Se a Lei em questão não estiver em conformidade com a Carta Magna, não deverá produzir efeitos e por consequência, considerados inconstitucionais.

Inconstitucionalidade seria qualquer manifestação do Poder Público, ou de quem possuir competência, comissiva ou omissiva, em desrespeito à Carta da República. Por isso se faz necessária a realização de um Controle de Constitucionalidade. Novelino assim define: "o controle de constitucionalidade consiste na fiscalização da compatibilidade entre as condutas dos poderes públicos e os comandos constitucionais, a fim de assegurar a supremacia da Constituição." (NOVELINO, 2009, p. 204).

Diante disso, é perceptível a crescente preocupação com a segurança jurídica em nosso ordenamento. $\bigcirc$ controle de leis perante a Lei Maior garante a coerência e ordem entre os Poderes, de forma a evitar danos aos direitos que estão em confronto com as leis brasileiras.

\section{I Sistemas de controle}

Os sistemas de Controle de constitucionalidade são considerados frutos da classificação quanto à competência. Com o fim da Segunda Guerra Mundial, tribunais europeus e norte-americanos passaram a adotar dois sistemas. De acordo com o órgão jurisdicional competente para a realização do controle, este pode ser difuso ou concentrado. A Constituição, de 1988, adotou o controle jurisdicional misto, cujo exercício pode ocorrer pelos dois sistemas supracitados.

\section{I.I Difuso}

Decorrente do sistema norte-americano, a competência para o exercício do controle difuso é atribuída a todos os órgãos do Poder Judiciário, aberta a qualquer juiz ou tribunal. Há outras denominações, como controle aberto, incidental, incidenter tantum, por via de exceção ou via de defesa.

Como essa modalidade dá-se no curso de uma ação submetida à apreciação do Poder Judiciário, todos os envolvidos poderão provocar o órgão jurisdicional para que declare a inconstitucionalidade da norma no caso concreto: o indivíduo se sentiu 
prejudicado juridicamente em decorrência de um dispositivo legal que considera inconstitucional, ingressa com ação no primeiro grau de jurisdição, questionando a própria inconstitucionalidade da norma como preliminar de mérito. Portanto, terão legitimidade para propor: as partes no processo, os terceiros admitidos como intervenientes no processo e o representante do Ministério Público.

Essa ação pode ser apreciada pelo STF, em grau de recurso extraordinário, o qual proferirá a decisão final a respeito da constitucionalidade da norma em questão. Diante desse caso concreto, tal apreciação acarreta efeito entre as partes, o que será aplicado apenas à situação fática que deu origem à ação. Tal efeito pode ser ampliado contra todos e terá abrangência e validade em todo o território brasileiro. Para tanto, é necessário que a decisão seja enviada ao Senado, que suspenderá a execução da lei, por meio de ato discricionário. Outro efeito marcante é o ex nunc, significando que os efeitos da decisão passam a ter força normativa a partir de sua prolação, não alcançando o início da discussão do tema.

\subsubsection{Concentrado}

Nesse sistema, o controle de constitucionalidade é exercido apenas por determinado órgão judicial, também denominado de controle abstrato, direto, ou via principal. A análise da inconstitucionalidade não se limita a um caso concreto, abrange todas as situações e divergências que possam surgir em decorrência da norma. Dessa forma, procede-se à verificação de compatibilidade da norma com a Constituição.

Por esse modelo de controle, é feita a declaração de inconstitucionalidade da lei ou do ato normativo, a fim de alcançar a invalidação da lei para firmar a segurança das relações jurídicas. Ao contrário do controle difuso, que possui natureza objetiva, por não haver partes litigantes envolvidas no processo. A discussão recai se uma lei é, ou não, inconstitucional, a fim de contribuir para a manutenção da supremacia constitucional. Possui efeito ex tunc, retroage no tempo desde a data da publicação da lei ou ato normativo inconstitucional. Excepcionalmente, preceitua o art. 27 da Lei n 9.868, de 1999:

Art. 27. Ao declarar a inconstitucionalidade de lei ou ato normativo, e tendo em vista razões de segurança jurídica ou de excepcional interesse social, poderá o Supremo Tribunal Federal, por maioria de dois terços de seus membros, restringir os efeitos daquela declaração ou decidir que ela só tenha eficácia a partir de seu trânsito em julgado ou de outro momento que venha a ser fixado.

Significa que o STF pode atribuir efeito ex nunc, de modo que a decisão se tornará eficaz somente após o trânsito em julgado da ação. Para esse procedimento exige-se voto de dois terços dos membros do STF. Faz-se presente, também, o efeito contra todos, acima mencionado. É uma consequência da via de ação. 
Portanto, diante de um pronunciamento do Supremo, passamos a ter uma decisão passível de ser enquadrada como definitiva. Nessa ocasião, nos dizeres do ministro Marco Aurélio Mello, nós exercemos a jurisdição restabelecendo, numa gradação maior, a paz social.

\section{TRIBUNALDE CONTAS}

\section{I Origem e evolução}

A descoberta das lavras de ouro na atual região dos estados de Minas Gerais, Bahia e Goiás, entre os séculos XVII e XVIII, causou grande repercussão na história econômica do Brasil colônia. Acreditava-se que no Brasil havia ouro e outros metais e pedras preciosas.

No entanto, passaram-se dois séculos de ocupação sem mérito quanto a esses recursos minerais, pois não eram encontrados em volume significativo. Ao longo do tempo, a economia colonial abandonou sua predominância extrativista para uma exploração mais racional e estável, devido à implantação dos engenhos de açúcar e das lavouras de tabaco que se espalharam por todo o litoral do Nordeste.

Diante disso, estimulados pela Coroa Portuguesa, os habitantes do Brasil passaram a desbravar o sertão em busca de ouro. Nesse contexto, com o intuito de racionalizar a ação fiscalizadora do Estado, por meio de um órgão centralizado, destinado a impor ordem sobre as rendas e tributos, instalou-se, por ordem de Dom João VI, o erário, que oferecia segurança à Coroa no fortalecimento das finanças públicas, juntamente com o Conselho da Fazenda, que tinha como função primordial acompanhar a execução da despesa pública. Enquanto essa inovação foi transformada em Tesouro da Fazenda, na Constituição, de 1824, o Erário Régio representou o primeiro centro de estruturação fazendária, o qual, posteriormente, originou o atual Ministério da Fazenda.

A iniciativa para a criação de um Tribunal de Contas no Brasil ocorreu em I 826, por um projeto de lei proposto no Senado por Visconde de Barbacena, Felisberto Caldeira Brandt e José Inácio Borges.

Em 1832, criou-se o Tribunal do Tesouro Público, em substituição ao Erário Régio, de forma que, anualmente, o ministro e o secretário de Estado da Fazenda deveriam apresentar à Câmara dos Deputados um balanço das receitas e despesas do exercício anterior, e, ainda, um orçamento para o ano seguinte.

Em I 844, iniciou-se a distinção entre as funções de administração e fiscalização, pois a Fazenda Pública passou a ser composta pela Secretaria de Estado dos Negócios da Fazenda, o Tribunal do Tesouro Público e o Conselho Fiscal de Contas. Em 1849, o Conselho Fiscal de Contas foi extinto, surgindo então o Tribunal de Contas.

Contudo, o primeiro Tribunal de Contas do país, o Tribunal de Contas da União, só foi criado em 1890, pelo Decreto 966-A, de 7 de novembro de 1890, por iniciativa de 
Rui Barbosa, ministro da Fazenda à época. A primeira Constituição que previu o Tribunal de Contas foi a de I89I no art. 89, conferindo a este órgão a competência para liquidar e verificar a legalidade das contas da receita e da despesa antes de serem prestadas ao Congresso Nacional. A instalação deste Tribunal ocorreu em 1893.

A Constituição, de 1934, ampliou as competências do Tribunal de Contas da União, conferindo-Ihe a função de proceder ao acompanhamento da execução orçamentária, do registro prévio das despesas e dos contratos, proceder ao julgamento das contas dos responsáveis por bens e dinheiro público e oferecer parecer prévio sobre as contas do presidente da República. Nas palavras de Pontes de Miranda:

A Constituição de 1934 considerou-o órgão de cooperação nas atividades governamentais. Ao antigo Tribunal de Contas - que a Constituição manteve (art.99 é mantido) - o texto de 1934 conferiu, assim, a mais, a atribuição de julgar as contas dos responsáveis por dinheiros ou bens públicos em toda a sua extensão. $\bigcirc$ acréscimo, em vez de o tornar órgão cooperador do Poder Executivo, acentuou o elemento judiciário que já ele tinha, inclusive pelo modo de composição e garantias de seus membros.(MIRANDA, 1970, p.248).

Segundo Pontes de Miranda, o Tribunal de Contas era um órgão sui generis do Poder Judiciário, com função auxiliar do Poder Legislativo, não se encaixando na interpretação rígida da Teoria da Tripartição dos Poderes. Na Constituição, de 1937, todas as competências trazidas pela Constituição, de 1934, foram mantidas, exceto oferecer parecer prévio sobre as contas presidenciais.

A Carta Magna, de 1946, manteve todas as competências da Constituição anterior e acresceu a função de o Tribunal de Contas julgar a legalidade das concessões de aposentadorias, reformas e pensões. Na Constituição, de 1967, houve o enfraquecimento do Tribunal de Contas.

Ocorreu a exclusão da atribuição de o Tribunal de Contas examinar e julgar previamente os atos e contratos geradores de despesas. Todavia, o órgão continuou a ter a função de apontar falhas e irregularidades que seriam objeto de representação ao Congresso Nacional, caso não fossem sanadas. Retirou-se, também, a atribuição de o Tribunal de Contas julgar a legalidade das concessões de aposentadorias, reformas e pensões, tendo o Tribunal competência apenas para a apreciação da legalidade para fins de registro.

Conforme observado, antes de 1988, o Tribunal de Contas restringia-se a fiscalizar aspectos contábeis, financeiros e orçamentários. A atual Carta Magna Ihe conferiu novas competências, mais adequadas à realidade do Estado contemporâneo. A inovação foi influenciada pela tendência mundial de preocupação com o bom funcionamento da administração pública, e a Corte de Contas adquiriu competência para fiscalizar aspectos operacionais e patrimoniais, e ainda, no tocante à legitimidade e à economicidade, com a finalidade de aumentar o grau de eficiência da administração. Desse modo, o órgão 
que já tinha destacado papel no controle da administração pública, passa a ser imprescindível.

A função fiscalizadora concretiza-se mediante inspeções, auditorias, acompanhamento e monitoramento nos diversos órgãos da administração. "No exercício de suas atribuições, o Tribunal de Contas, à vista de determinada irregularidade ou ilegalidade, pode recomendar ao responsável que tome medidas no sentido de corrigi-las, desenvolvendo assim sua função corretiva." Também atua como ouvidoria, de modo a receber denúncias e representações contra a administração pública por parte de autoridades, partidos políticos, sindicatos, associações ou qualquer cidadão.

No que tange à sua posição institucional, a Corte de Contas procede como órgão autônomo, o qual está destinado a efetuar o controle externo dos três poderes da República Brasileira. Presta auxílio ao Poder Legislativo sobre as contas prestadas pelo presidente da República e apresenta perfil de tribunal judicial, tendo em vista que na apreciação de determinadas matérias decide definitivamente, aplicando penas, conforme exposto anteriormente.

\section{ATRIBUIÇÕES E COMPETÊNCIAS DO TRIBUNAL DE CONTAS}

Tribunal de Contas é um órgão garantidor dos direitos fundamentais, pois fiscaliza a movimentação financeira e patrimonial do Estado. Executa atos de natureza administrativa, direcionados à fiscalização. Assim, De Plácido e Silva define:

É o órgão que, como representante do povo, é colocado na Administração Pública, a fim de coordenar e fiscalizar os negócios da Fazenda Publica, acompanhando a execução da lei orçamentária e julgando as contas dos responsáveis por dinheiro, ou bens públicos. Precisamente, porque se ressalta nele o poder de tomar contas dos encarregados da gestão financeira do país, e particularmente individualizado pela expressão de Contas. (SILVA, 2006).

Portanto, é incumbido de auxiliar os órgãos da administração pública na realização de seu controle interno, o qual compreende um conjunto de procedimentos adotados pelas entidades públicas para comprovar a legalidade e avaliar seus resultados. Chamase autocontrole quando exercido sobre a própria atuação do controlador responsável pela fiscalização. Ressalta-se que a atividade de controle é inerente à própria existência humana, especialmente quanto ao controle do patrimônio. $\bigcirc$ orçamento pessoal depende do controle que se faz sobre as despesas de forma a compatibilizar a receita com os gastos realizados em determinado período.

$\bigcirc$ controle dos gastos segue um cronograma constituído de planejamento, orçamento, execução e controle. Os administradores devem utilizar ações para efetivo controle dos gastos públicos, pois compreendem os recursos da sociedade que são geridos pelos agentes públicos em prol da coletividade. $\bigcirc$ doutrinador Hely Lopes Meirelles considera o controle como: " ... a faculdade de vigilância, orientação e correção 
que um Poder, órgão ou autoridade exerce sobre a conduta funcional de outro".

Dessa forma, o Tribunal de Contas da União presta auxílio ao Congresso Nacional no exercício do controle externo da administração dos três Poderes da União, mas não deixa de manifestar vontade constitucional. Após a ampliação de seus poderes, sua competência ultrapassa a mera análise da legalidade formal, pois passa a verificar a consonância dos atos dos administradores, gestores e órgãos com os princípios constitucionais, previstos no artigo 37 da Constituição Federal. E ainda possui o condão de, por iniciativa própria, realizar inspeções e auditorias de natureza contábil, financeira, orçamentária, operacional e patrimonial, nas unidades administrativas dos três Poderes, e demais entidades referidas no inciso II do artigo 7I, bem como na Câmara dos Deputados, do Senado Federal, de Comissão técnica ou de inquérito, nos termos do inciso IV do mesmo dispositivo legal.

A Constituição da República Brasileira prevê expressamente a composição, garantias e a forma de escolha dos membros do Tribunal de Contas da União, em seu artigo 73, em que apresenta a organização estrutural, bem como a ideia de garantir a independência e autonomia dos membros, e consequentemente sua instituiçã̃o.

É válida a observação de que há, por diversas vezes, a tentativa de se extinguirem os Tribunais de Contas dos Municípios sob o argumento de economia. No entanto, a ideia não predominou no sistema brasileiro, pois seria contraditório extinguir unidade de controle específico que faz economia sob tal argumento. O Supremo Tribunal Federal manifestou entendimento de que as constituições estaduais podem criar Tribunal de Contas dos Municípios.

\section{I Natureza jurídica dos Tribunais de Contas}

No que tange à natureza jurídica do Tribunal de Contas, existem certas discussões e polêmicas sobre o assunto, ainda não pacificado na doutrina e jurisprudência. A Constituição Federal trata desse órgão em capítulo conferido ao Poder Legislativo, de modo específico, na seção sobre as normas referentes à fiscalização contábil, financeira e orçamentária.

Há certa independência taxativa entre o Poder Executivo e a Cortes de Contas. Nesse sentido, o jurista Carlos Roberto Siqueira Castro reconhece a necessidade de se "permitir o pleno exercício da função fiscalizatória em face da administração da receita e da despesa pública, que são exercidas pelos três Poderes da República".

Ressalta-se que parte da doutrina defende que tais tribunais exercem funções jurisdicionais, muito embora não estejam incluídos no Poder Judiciário. Contudo, existem correntes doutrinárias que consideram os Tribunais de Contas como órgãos subordinados hierarquicamente ao Poder Legislativo, em razão de sua posição de auxiliar, devido à expressão "com auxílio do Tribunal de Contas", prevista no art. 7। da atual Constituição. No entanto, conforme aduz o ministro do STF, Carlos Ayres Brito: 
Os julgamentos legislativos se dão por um critério dotado de discricionariedade para avaliar fatos e pessoas, ao passo que as decisões emanadas do pretório em comento só podem obedecer a parâmetros de ordem técnico-jurídica, isto é, parâmetros de subsunção de fatos e pessoas à objetividade das normas constitucionais legais. (BRITTO, 200I).

Evidentemente, tais órgãos elaboram o seu próprio Regimento Interno e possuem autonomia administrativa e financeira de modo pleno, gerindo e decidindo as questões da sua economia interna. Além disso, ainda podem propor a iniciativa de lei, em especial sobre assuntos de sua administração, a teor do que prescreve o caput do artigo 73 da Carta. Ademais, numa tentativa de evitar qualquer tipo de dúvida, Jarbas Maranhão afirma:

\begin{abstract}
Em relação ao Poder Executivo, a função do Tribunal de Contas é de controle e revisão. (...) Relativamente ao Poder Legislativo que, além de legislar, tem amplo poder de fiscalização, o Tribunal de Contas coopera tecnicamente na realização do Controle Externo. Quanto ao Poder Judiciário tem com ele similitudes. Como órgão tem composição não idêntica, mas semelhante. Os ministros e conselheiros do Tribunal de Contas têm os mesmos direitos, garantias e impedimentos dos Magistrados do Poder Judiciário. ("Tribunal de Contas: Jurisdição Peculiar", Revista do TCE/PE, n I3, p. 86-88).
\end{abstract}

No mesmo raciocínio, Alexandre de Moraes entende que "o Tribunal de Contas é órgão auxiliar e de orientação do Poder Legislativo, embora a ele não subordinado, praticando atos de natureza administrativa, concernentes, basicamente, à fiscalização".

Diante disso, é possível verificar a natureza de órgãos constitucionais, providos de autonomia administrativa e financeira, sem vínculo de subordinação com os Três Poderes, tendo em vista que agem ora em colaboração com o Poder Legislativo, ora no exercício de competências próprias.

\title{
4.2 Tribunal de Contas da União
}

O julgamento de contas dos administradores públicos constitui a base do sistema de controle externo. A possibilidade de o Tribunal de Contas realizar atividades referentes à fiscalização, como levantamento, auditoria, inspeção e monitoramento, previstas nos arts. 238 a 243 do Regimento Interno do TCU, configura o meio para se instruir o julgamento das contas. Trata-se de instrumento que responsabiliza o gestor público, de forma individual, imputando-se-lhe o dever de prestar as respectivas contas e os recursos públicos que lhe foram confiados.

Grande parte da sociedade brasileira desconhece essa jurisdição exercida sobre os gestores públicos, e alguns doutrinadores acabam por considerá-la como mera contabilização de valores. Enquanto que, na realidade, essa matéria especialíssima de 
jurisdição foi confiada com exclusividade às Cortes de Contas, como uma das exceções, previstas na Constituição ao princípio da inafastabilidade do Poder Judiciário.

O tema não é pacífico na doutrina, conforme os dizeres de FERNANDES (2003; p. 138): "No atual modelo constitucional positivo, ficou indelevelmente definido o exercício da função jurisdicional pelos tribunais de contas". Nesse sentido, Athos Gusmão Carneiro explica de forma clara:

Os tribunais de contas têm atribuições de natureza administrativa. Entretanto, quando "julga" as contas dos administradores e demais responsáveis por bens e valores públicos, tal julgamento impõem-se ao poder judiciário, no que concerne ao aspecto contábil, sobre a regularidade da própria conta. (CARNEIRO, 1983, p. 13).

Apesar da previsão constitucional de sua organização, a Lei Orgânica do Tribunal de Contas da União (Lei n 8.443, de 16 de julho de 1992) especifica e determina como se compõe a instituição. Há nove membros que são denominados ministros; destes, seis são indicados pelo Legislativo; e três pelo Executivo. A escolha deve atender aos requisitos mínimos, quais sejam, que os ministros tenham mais de trinta e menos de sessenta e cinco anos, idoneidade moral e reputação ilibada, notórios conhecimentos em uma das seguintes áreas, jurídica, contábil, econômica, financeira ou de administração pública e mais de dez anos de exercício ou de efetiva atividade profissional que exija os conhecimentos mencionados.

Além disso, haverá ministros substitutos, nomeados pelo presidente da República, dentre os cidadãos que satisfaçam os requisitos exigidos para o cargo de ministro do Tribunal, mediante concurso público de provas e títulos.

Suas competências estão previstas no art. $1^{\circ}$ da Lei nº 8.443, de 1992, entre elas destacam-se:

I. Julgar as contas dos administradores e demais responsáveis por dinheiros, bens e valores públicos das unidades dos poderes da União e das entidades da administração indireta (...);

II. Proceder, por iniciativa própria ou por solicitação do Congresso Nacional, de suas Casas ou das respectivas comissões, à fiscalização contábil, financeira, orçamentária, operacional e patrimonial das unidades dos poderes da União e das demais entidades referidas no inciso anterior;

III. Apreciar as contas prestadas anualmente pelo Presidente da República, nos termos do art. 36 desta Lei;

IV. Acompanhar a arrecadação da receita a cargo da União e das entidades referidas no inciso I deste artigo, mediante inspeções e auditorias, ou por meio de demonstrativos próprios, na forma estabelecida no Regimento Interno;

V. Apreciar, para fins de registro, na forma estabelecida no Regimento Interno, a legalidade dos atos de admissão de pessoal, a qualquer título, na administração 
direta e indireta.

(...).

Tratando-se de sua estrutura, enquadram-se como órgãos deliberativos: o Plenário, composto pela totalidade dos ministros - conduzido pelo presidente do Tribunal -; a Primeira e a Segunda Câmara, cada uma composta por quatro ministros, que a integram por dois anos, com recondução automática.

\subsection{Tribunal de Contas dos Estados e no Distrito Federal}

artigo 75 da Constituição Federal prevê que as normas estabelecidas para o Tribunal de Contas da União aplicam-se, no que couber, à organização, composição e fiscalização dos Tribunais de Contas dos Estados e do Distrito Federal, bem como dos Tribunais e Conselhos de Contas dos Municípios. Tais órgãos devem se constituir de sete conselheiros, correspondentes aos ministros do Tribunal de Contas da União, e terão as mesmas garantias e prerrogativas, impedimentos, vencimentos e vantagens dos desembargadores do Tribunal de Justiça do respectivo estado ou Distrito Federal.

O STF reconhece que o modelo de organização e estruturação, bem como os requisitos para nomeação dos membros do Tribunal de Contas da União serão reproduzidos na Constituição dos Estados-Membros, e, de igual modo, serão aplicados para a nomeação dos conselheiros. É válida a observação de que o dispositivo constitucional esclarece "no que couber", características gerais, mas deixa as peculiaridades locais ou particulares para uma normatização adequada.

A obrigação dos Tribunais de Contas dos estados e Distrito Federal encontra-se no artigo 84, XXIV, da CF, de 1988, para fiscalizar as contas dos estados, municípios e Distrito Federal. A prestação de contas compete privativamente ao presidente da República apresentar, anualmente, ao Congresso Nacional, no prazo de até sessenta dias após a abertura da sessão legislativa, as contas referentes ao exercício anterior.

Nesse caso, em virtude da "simetrização", tal obrigação se estenderá ao governador do Estado e aos prefeitos municipais, representando a União, o Estado ou Distrito Federal ou o Município. Nesse sentido, ambos terão suas atribuições determinadas em lei específica que estabelece o regimento interno.

Portanto, exercem o controle financeiro sobre a administração pública estadual e elaboram o parecer quanto às contas das respectivas Assembleias Legislativas. $\bigcirc$ controle externo exercido tem o alcance de fiscalizar as contas anuais prestadas pelo governador, emitir parecer prévio e julgar as contas dos administradores e demais responsáveis por dinheiro, bens e valores da administração direta e indireta e que estejam sob sua responsabilidade.

Estão incluídas as fundações e sociedades instituídas ou mantidas pelo poder público; a legalidade dos atos de admissão de pessoal da administração direta e indireta; a avaliação das execuções orçamentárias, composição de comissões, realização por 
iniciativa própria ou a pedido, de auditoria de natureza contábil, financeira, orçamentária, operacional e patrimonial, dentro de sua jurisdição ou circunscrição, abrangendo os Poderes Legislativo, Executivo e Judiciário; e aplicar aos responsáveis as sanções previstas em lei específica, quando houver ilegalidade de despesa ou irregularidade de contas, como multa proporcional ao dano causado.

\subsection{Tribunal de Contas do Estado do Tocantins}

A Constituição Estadual do Tocantins prevê a competência, organização e estruturação de sua respectiva Corte de Contas, na seção que versa sobre a Fiscalização Contábil, Financeira e Orçamentária. O referido órgão possui legislação própria, por meio da Lei Orgânica Estadual n 1 .284, de 17 de dezembro de 200 I , e seu Regimento Interno $n^{\circ}$ 002, de 2002. Ambos definem suas funções precípuas e dispõem das atribuições gerais e o modo de processar e julgar as contas, sempre sob a luz dos princípios administrativos.'

Em atenção à Lei Maior, a Lei Orgânica n 1.284, de 200।, imputa ao Tribunal de Contas do Tocantins a importante função de apreciar as contas prestadas a cada ano pelo governador e prefeitos municipais e demais atividades que envolvam dinheiro e bens de interesse público.

Igualmente, podemos destacar como função precípua: julgar as contas dos ordenadores de despesa e demais responsáveis pela esfera que envolve o erário; apreciar a legalidade dos atos de admissão de pessoal, a qualquer título; avaliar a execução das metas previstas no plano plurianual, nas diretrizes orçamentárias e no orçamento anual; realizar inspeções e auditorias de natureza contábil, financeira, orçamentária, operacional e patrimonial, nas unidades administrativas dos Três Poderes, bem como Ministério Público e demais entidades da administração. Em consequência dessa atividade, caberá também aplicar aos ordenadores de despesa, aos gestores e aos responsáveis por bens e valores públicos as multas e demais sanções previstas nessa Lei.

A referida Corte é encarregada pelo Regimento Interno, em seu artigo $2^{\circ}$, de satisfazer as necessidades da sociedade, quanto à correta aplicação dos recursos públicos, garantindo a esta um transparente e eficaz sistema de fiscalização da gestão pública. Sua jurisdição é própria e privativa em todo o território de seu Estado, por conseguinte, possui competências específicas sobre a execução do controle externo dos órgãos e entidades da administração direta e indireta, até mesmo das fundações instituídas e mantidas pelo Poder Público do Estado e dos Municípios, nos termos das

\footnotetext{
' Legalidade, Impessoalidade, Moralidade, Pessoalidade e Eficiência.
} 
Constituições Federal e Estadual e da sua Lei Orgânica. Por conseguinte, o art. $5^{\circ}$ do Regimento confere amplitude aos Poderes da Corte, algo que se destacou como inovação, tornando sua atuação ainda mais eficaz.

\section{CONTROLE DE CONSTITUCIONALIDADE EXERCIDO PELO TRIBUNAL DE CONTAS}

Conforme exposto, a Constituição Federal, de 1988, conferiu aos Tribunais de Contas o controle da legalidade dos atos da Administração, pertinente a matérias que envolvem despesas públicas. Essa atividade possibilita a realização da análise comparativa do ato perante a lei, até mesmo a Lei Suprema, pelo órgão supracitado. Por conseguinte, compete-lhes examinar a validade das leis, em tese, em caráter "consulta", como instrumento de análise de dúvida suscitada na aplicação de dispositivos legais e regulamentares, concernentes à matéria de sua competência.

entendimento tem sido pacífico, tanto a doutrina quanto a jurisprudência estão apoiando a discussão, no sentido de que a Corte de Contas pode e deve se manifestar acerca da constitucionalidade de leis e atos normativos, em matérias de sua competência. Suponha-se, por exemplo, que determinado Município edite uma lei e crie cargos públicos sem observar as disposições constitucionais precisas, evidentemente, torna-se imprescindível o poder de o Tribunal de Contas averiguar o conflito existente e suas consequências e emitir um juízo de constitucionalidade, a fim de impedir a realização das despesas decorrentes.

\section{I Súmula 347 do STF}

Supremo Tribunal Federal autorizou expressamente ao Tribunal de Contas a realização do Controle de Constitucionalidade, pela Súmula 347: O Tribunal de Contas, no exercício de suas atribuições, pode apreciar a constitucionalidade das leis e dos atos do poder público. Tal órgão somente poderá julgar inconstitucional uma lei ou ato normativo nos casos in concreto, ou seja, deve incidir sobre um fato concreto, vinculado a um processo em trâmite na respectiva Corte, para que não haja usurpação do Supremo Tribunal Federal.

Todavia, há de se ressalvar que o tema em questão repercute no mundo jurídico, sobretudo porque a Suprema Corte, em diversas decisões monocráticas, suscitou a necessidade de revisão da Súmula supracitada, pelo fato de ser exarada em momento anterior ao da Constituição Federal vigente. Portanto, o entendimento segue no sentido de que é válida a declaração de inconstitucionalidade pelo Tribunal de Contas para afastar a aplicação da lei ou ato normativo no caso concreto, porém, há certa tendência emalterar esse panorama.

Em sede do Mandado de Segurança 25888 MC/DF, o ministro Gilmar Mendes 
alegou que não cabe ao TCU declarar a inconstitucionalidade de determinada norma, e explicou:

Assim, a declaração de inconstitucionalidade, pelo Tribunal de Contas da União, do art. 67 da Lei n ${ }^{\circ}$ 9.478/97, e do Decreto ${ }^{\circ}$ 2.745/98, obrigando a Petrobrás, consequentemente, a cumprir as exigências da Lei n 8.666/93, parece estar em confronto com normas constitucionais, mormente as que traduzem o princípio da legalidade, as que delimitam as competências do TCU (art. 7I), assim como aquelas que conformam o regime de exploração da atividade econômica do petróleo (art. 177). Não me impressiona o teor da Súmula n 347 desta Corte, segundo o qual "o Tribunal de Contas, o exercício de suas atribuições, pode apreciar a constitucionalidade das leis e dos atos do Poder Público. A referida regra sumular foi aprovada na Sessão Plenária de 13.12.1963, num contexto constitucional totalmente diferente do atual. Até o advento da Emenda Constitucional $n^{\circ} 16$, de 1965, que introduziu em nosso sistema o controle abstrato de normas, admitia-se como legítima a recusa, por parte de órgãos nãojurisdicionais, à aplicação da lei considerada inconstitucional.

(...) Assim, a própria evolução do sistema de controle de constitucionalidade no Brasil, verificada desde então, está a demonstrar a necessidade de se reavaliar a subsistência da Súmula 347 em face da ordem constitucional instaurada com a Constituição de 1988. (MS 25888 MC / DF - MEDIDA CAUTELAR NO MANDADO DE SEGURANÇA. Rel.: Min. GILMAR MENDES. 22/03/2006. DJ 29/03/2006 PP-000 I I).

Pensa-se que tal manifestação teria eliminado a aplicabilidade da Súmula 347 do STF. É certo que após a atual Carta Magna estabeleceu-se que apenas um órgão de cúpula tivesse o poder de declarar o que é, ou não, constitucional, atribuindo-se ao seu guardião essa competência.

Pedro Lenza ressalta sua posição com base na Súmula proferida anteriormente à nova Constituição, e explica que, em se tratando de controle difuso e no exercício de suas atribuições, o TCU pode sim apreciar a constitucionalidade de uma norma, assim como deixar de aplicá-la quando entender que ela é flagrantemente inconstitucional. (2008, p. | 42.)

A Súmula n 347 foi adotada em 13 de dezembro de 1963, tendo por base o julgado do MS n 8.372 - CE, de II de dezembro de 196I, da relatoria do ministro Pedro Chaves, ao tratar de recurso de aposentado como delegado de polícia substituto contra decisão do TCE/CE, no qual se negou a efetuar o registro ao ato de aposentadoria e contra decisão do Tribunal de Justiça do Estado do Ceará e manteve a decisão do Tribunal de Contas, o ministro relator negou provimento ao recurso:

Nego provimento ao recurso. Considerando sem efeito a lei que servira de fundamento ao ato de aposentadoria do recorrente, não poderia ser feito o registro por falta de supedâneo jurídico. A meu ver o acórdão recorrido bem 
decidiu a espécie, mas não posso deixar de the opôr um reparo de ordem doutrinaria, pois não quero ficar vinculado a uma tese que tenho constantemente repelido. Entendeu o julgado que o Tribunal de Contas não poderia declarar a inconstitucionalidade da lei. Na realidade, esta declaração escapa à competência específica dos Tribunais de Contas. Mas há que distinguir entre declaração de inconstitucionalidade e não aplicação de leis inconstitucionais, pois esta é a obrigação de qualquer tribunal ou órgão de qualquer dos poderes do Estado. Feita essa ressalva, nego provimento ao recurso.

Sob análise do especialista em Direito Público Cláudio Marcelo Spalla Farjado, o ministro relator baseia-se nas seguintes premissas: a) toda lei ou ato normativo inconstitucional é nulo, e não pode produzir efeitos; b) por ser inexistente, o Tribunal de Contas, assim como todos os poderes da administração pública têm este poder-dever de afastar a aplicação da norma jurídica marcada pela inconstitucionalidade; c) não obstante, só o Poder Judiciário tem a competência para declarar a inconstitucionalidade de leis ou atos normativos.

Os itens supracitados configuram o pensamento da época, mas colidem com teses mais modernas. Vários autores se pronunciaram em prol dessas teses, de sorte que até nos dias de hoje ecoam em nosso meio jurídico.

Para que não haja equívoco, a interpretação deve seguir no sentido de que o Supremo julga a lei, confere-lhe validade, ou não, conforme esteja afinada, ou não, ao texto constitucional; e aos Tribunais de Contas é assegurada a competência de declarar a inaplicabilidade do texto legal apreciado ou determinar a sustação do ato que não se conforme com a Lei Maior.

Faz- se necessário, portanto, distinguir declaração de inconstitucionalidade e não aplicação de leis inconstitucionais, como bem assinala o excerto do Recurso em Mandado de Segurança no 8.372 do STF. Esta é uma obrigação atribuída a qualquer Tribunal ou órgão de algum dos poderes do Estado. Logo, é considerável que os Tribunais de Contas deixem de aplicar leis inconstitucionais, embora essa competência não seja privativa deles.

\subsection{Controle de constitucionalidade exercido pelo Tribunal de Contas do Estado do Tocantins}

Tanto a Lei Orgânica $\mathrm{n}^{\circ}$ I.284, de 200।, quanto o atual Regimento Interno do TCE/TO tratam "Dos Incidentes de Inconstitucionalidade", presentes nos art. 68 da referida Lei e 263 do Regulamento Geral, vejamos:

Art. 68. Se por ocasião do julgamento de qualquer feito pela Câmara, esta verificar a inconstitucionalidade de alguma lei ou ato do Poder Público, os autos serão remetidos a discussão em Sessão do Tribunal Pleno para pronunciamento 
preliminar sobre a matéria.

$\S 1{ }^{\circ}$ Na primeira Sessão Plenária o relator do feito exporá o caso, procedendose em seguida a deliberação sobre a matéria.

$\S 2^{\circ}$ Proferido o julgamento pelo Tribunal Pleno e publicada a respectiva deliberação, serão os autos devolvidos à Câmara para apreciar o caso de acordo com a decisão prejudicial.

E, ainda, presente no RG:

Art. 294 -Ao Tribunal Pleno, dirigido pelo Presidente do Tribunal, compete:

(...)

$\mathrm{XI}$ - decidir incidentes de inconstitucionalidade;

A eficácia do controle de constitucionalidade difuso exercido pelo Tribunal de Contas do Estado do Tocantins se faz presente em diversos julgados. ${ }^{2} \bigcirc$ julgamento sobre a constitucionalidade de um preceito legal exercida pelos Tribunais de Contas, no exercício de sua função e concernente à matéria de sua competência, gera efeitos de grande valia e alcança todos os órgãos e entes jurisdicionados, orientando-os e vinculando-os. Daí surge a reflexão sobre o relevante papel desses Tribunais Contas no controle das despesas públicas.

Nesse diapasão, surgem diversos questionamentos a respeito dessa eficácia e da validade do Controle de Constitucionalidade realizado pela Corte de Contas do Estado. Daí a necessidade de se adaptar cada situação concreta aos Princípios Jurídicos Formais, para assegurar harmonia em cada ente federativo.

Evidentemente, o Poder de exercer tal Controle, quando atribuído ao Tribunal de Contas, respeitando os Princípios que regem o Sistema, acarreta segurança para a sociedade enquanto parte de um Estado Democrático de Direito, considerando-se que dessa forma podem-se evitar condutas abusivas, principalmente por parte do Poder Público.

O tema gerou discussão, por volta de 2010 , em que a Associação dos Membros dos Tribunais de Contas do Brasil (ATRICON) propôs Ação Direta de Inconstitucionalidade $n^{\circ} 4.4$ I 8, perante o STF, com pedido liminar, contestando a norma $n^{\circ} 2.352$, de 2010 , que alterou a Lei Orgânica do Tribunal de Contas do Tocantins (Lei n I.284, de 200 I). A ação teve respaldo sob o argumento de que a Lei contestada afeta as atribuições e autonomia da Corte de Contas Tocantinense. Salienta a ação:

${ }^{2}$ Acórdãos 372, de 2009 - TCE/TO Pleno; 22, de 2005 - TCE/TO Pleno; Processo 5.698, de 2011 . 


\begin{abstract}
"A lei em questão representa um inegável retrocesso na história brasileira dos Tribunais de Contas, cuja finalidade maior é identificar, frear e contribuir para a erradicação da improbidade administrativa, do desvio de verbas públicas e do prejuízo ao erário. Especificamente, parte significativa das atribuições e competências do Tribunal de Contas tocantinense foi alterada ou revogada pela Assembleia Legislativa, causando inegável prejuízo à população que aguarda, da atuação do Tribunal de Contas, o eficaz combate aos atos de improbidade que envergonham o povo brasileiro."
\end{abstract}

Observa-se que a nova lei interferiu de forma negativa na competência do TCE/TO, para julgar e atuar no reajuste dos valores de multa; alterar deveres dos membros do Ministério Público no TCE; e em diversas outras incoerências que foram criadas nesse sentido.

Segundo a associação, "a violação dessa competência agride a independência e a harmonia que deve haver entre os Poderes, além de ferir princípios do Estado Democrático de Direito." Ao final, requer a suspensão liminar da norma com efeitos retroativos para evitar suposto conflito entre o Tribunal de Contas e o Poder Legislativo Tocantinense, por violação aos princípios constitucionais da razoabilidade e da proporcionalidade. Segue a ementa do Acórdão proferido pelo Supremo:

Ação direta de inconstitucionalidade. ATRICON. Lei estadual (TO) n².35I, de I I de maio de 20 I 0. Inconstitucionalidade formal. Vício de iniciativa. Violação às prerrogativas da autonomia e do autogoverno dos Tribunais de Contas. I. Inconstitucionalidade formal da Lei estadual, de origem parlamentar, que altera e revoga diversos dispositivos da Lei Orgânica do Tribunal de Contas do Estado do Tocantins. A Lei estadual $n^{\circ}$ 2.35I/ 2010 dispôs sobre forma de atuação, competências, garantias, deveres e organização do Tribunal de Contas estadual. 2. Conforme reconhecido pela Constituição de 1988 e por esta Suprema Corte, gozam as Cortes de Contas do país das prerrogativas da autonomia e do autogoverno, o que inclui, essencialmente, a iniciativa reservada para instaurar processo legislativo que pretenda alterar sua organização e seu funcionamento, como resulta da interpretação sistemática dos artigos 73, 75 e 96, II, "d", da Constituição Federal (cf. ADI I.994/ES, Relator o Ministro Eros Grau, DJ de 8/9/06; ADI no 789/DF, Relator o Ministro Celso de Mello, DJ de 19/I2/94). 3. Deferido o pedido de medida cautelar para suspender a eficácia da Lei $n^{\circ} 2.351$, de I I de maio de 20 I0, do Estado do Tocantins, com efeitos ex tunc.

A Corte de Contas Tocantinense tem se antecipado às situações jurídicas contaminadas de inconstitucionalidade, com inegáveis benefícios para o patrimônio público. A título de exemplo, o processo n 5 5.698, de 20 I I, do TCE/TO, o qual trata de auditoria realizada no município de Peixe/TO, na qual foi constatada a alteração dos subsídios dos vereadores de forma ilegal, desrespeitando o princípio da anterioridade e a realização, por parte do presidente da Câmara, pagamentos indevidos para si e demais 
vereadores, contrariando a Constituição Federal, a orientação deste Tribunal e os demais princípios de ordem administrativa. Segue parte do Acórdão ${ }^{3}$ ao qual se negou executoriedade à irregularidade e ilegalidade praticada:

Resolução no $101 / 2012$ - TCE/TO PLENO (...). Considerando que é suscitada no presente processo negativa de executoriedade de dispositivo de Lei Municipal, matéria que, por envolver o reconhecimento da inconstitucionalidade da Lei ou ato do Poder Publico, se insere na reserva de plenário prevista no Art. 97 da Constituição da Republica, conforme preconiza a Sumula Vinculante n’ 10 do Supremo Tribunal Federal; Considerando, que é suscitada no presente processo negativa de executoriedade de dispositivo de Lei Municipal, mátria que, por envolver o reconhecimento de inconstitucionalidade de Lei ou ato do Poder Publico, se insere na reserva de plenário prevista no Art. 97 da Constituição da Republica; Considerando a competência do Tribunal de Contas em se pronunciar incidentalmente acerca da constitucionalidade de Leis e atos do Poder Publico; Considerando o enunciado da sumula n 347 do STF: 'o Tribunal de Contas, no exercício de suas atribuições, pode apreciar a constitucionalidade de leis e dos atos do poder publico'; Considerando que compete ao Tribunal de Contas realizar, por iniciativa própria, auditorias de natureza de natureza contábil, financeira, orçamentária, operacional e patrimonial. RESOLVEM os Conselheiros do Tribunal de Contas do Estado, reunidos em Sessão Plenária, com fundamentos nos artigos 33, II, da Constituição Estadual, art. I ${ }^{\circ}$, VI da Lei I.284/200 I c/c artigos 125 e 263 do Regimento Interno do TCE/TO, em: 9. I Rejeitar as razões de justificativas apresentadas pelos responsáveis quanto ao achado de auditoria que destaca a fixação a fixação, durante a legislatura, de novos subsídios dos vereadores de forma ilegal, sem respeitar o principio da anterioridade, bem como pagamentos indevidos para os demais vereadores, em desacordo com o estabelecido pela Lei Municipal no 569/2008, contrariando a Constituição Federal e a orientação deste TCE/TO; NEGAR EXECUTORIEDADE ao parágrafo $2^{\circ}$ do Art. $1^{\circ}$ e art. $2^{\circ}$ da Lei Municipal ${ }^{\circ}$ 569/2008, no que concerne ao reajuste automático, na mesma data e proporção a majoração do teto dos subsídios do Deputado Estadual e pagamento por convocação a sessões extraordinárias; NEGAR EXECUTORIEDADE a Resolução nº 04/20 I 0 e art. $1^{\circ}$, inc. I, da Resolução n 00 I/200 I, concernente ao reajuste e fixação de subsídios dos Vereadores, sem a observância do principio da anterioridade, nos termos da Sumula n 347 do STF, determinando, como consectário, a desconstituição do ato de pagamento dos subsídios realizados em conformidade com a Resolução $n^{\circ} 001 / 2011$, permanecendo o valor fixado na Lei Municipal n 569/2008 a titulo de subsídio de vereadores. Determinar (...) a adoção de medidas para fazer cessar o pagamento de valores supostamente indevidos e consequentemente proceder a sua devolução.

\footnotetext{
${ }^{3}$ Processo no 5.698 , de 20 I I, fls. I 24- I 26-TCE/TO Pleno;
} 
Com respaldo na antiga Súmula n 347, do STF, no artigo 293 de seu Regimento Interno, e no princípio da anterioridade, nos termos do voto da conselheira-relatora Doris de Miranda Coutinho, foi negada executoriedade da Lei Municipal n 569, de 2008, por contrariar a Carta Magna e outros dispositivos legais concernentes ao Tribunal de Contas. $\bigcirc$ aumento de subsídio impugnado afetaria o dinheiro público de forma injusta para com os cidadãos tocantinenses. Haja vista a ilegalidade do feito, a quantia deveria se destinar a gastos que atendessem ao interesse público, e não ao interesse particular dos administradores.

No mesmo sentido, o conselheiro-relator julgou, em 2005, incidente de inconstitucionalidade em face do prefeito do município de Palmeirópolis/TO, por receber subsídios dos agentes políticos municipais com valores superiores aos estabelecidos pela Constituição Estadual. Com apoio na ADI 2. I I2-5, do STF, que reconheceu inconstitucional a imposição de limites aos subsídios de prefeitos e viceprefeitos municipais, e o artigo 67-A da Constituição Estadual que impôs tais regras, o acórdão n 22, de 2005, do TCE/TO reconheceu a inconstitucionalidade do dispositivo da Carta Estadual, também com base na Súmula n 347, do STF e no artigo 293 de seu Regimento Interno.

\section{CONSIDERAÇÕES FINAIS}

A importância do Controle de Constitucionalidade realizado pelos Tribunais de Contas é nítida aos olhos, haja vista infelizmente ainda existirem falhas significantes no sistema pátrio, na economia, na sociedade e principalmente na política e nos atos administrativos. Dessa forma, a atuação desses Tribunais, no Controle, contribui para a concretização de um Estado Democrático de Direito.

As diversas atividades podem ser resumidas em administrativas, jurisdicionais e legislativas. Por sua vez, o Controle de Constitucionalidade figura como prerrogativa necessária, decorrente de uma função especial de apreciar a legalidade dos atos da administração pública. Portanto, esse controle permanece válido, como instrumento útil para a efetivação de suas competências.

Evidentemente, não se pode deixar de ressaltar a importância que o Tribunal de Contas exerce na organização do Ordenamento Brasileiro. Sensível se faz a evolução dos mecanismos de controle à disposição dessa instituição, mas, à medida que avançam, tendem a atender ao ideal previsto na Constituição da República. Sua inexistência, portanto, geraria desequilíbrio no sistema de "freios e contrapesos" do Estado, pelo fato de exercer fiscalização em alguns atos dos Três Poderes, de modo imparcial e desvinculado de qualquer um deles. Fiscalização essa que tem de ser reforçada cada vez mais, na intenção de se construir uma sociedade mais democrática e com melhor aproveitamento do dinheiro público.

Embora muitas vezes o sistema não siga de forma perfeita e harmônica como deveria ocorrer, se forem realizados alguns ajustes e observados os princípios 
constitucionais, os Tribunais de Contas poderão contribuir de forma extraordinária e cumprir sua função social, ainda que sejam castigados pelo mau da corrupção.

Ademais, é valido afirmar que tal Corte pode examinar a constitucionalidade das leis e atos normativos e, por essa ocasião, declará-los inconstitucionais, com o fim de afastálos da aplicação a um caso concreto. No entanto, somente se procederá diante da via incidental, controle difuso e com efeitos restritos às partes relativas aos processos submetidos à sua apreciação, e em matérias de sua competência.

Contudo, diante do estabelecido pela Constituição, a interpretação das leis e atos normativos realizada nas decisões prolatadas pelo Tribunal de Contas possui caráter informativo e orientador para todos os órgãos jurisdicionados. E mais, o feito servirá de precedente para uniformização de sua jurisprudência, subsidiando outros novos julgamentos pela irregularidade, caso haja reincidência, no âmbito da lei ou ato normativo eivado do vício da inconstitucionalidade.

Assim, o referido controle de constitucionalidade exercido pela Corte de Contas torna-se eficaz pelos motivos expostos e, principalmente, por prevenir a ocorrência de despesas inconstitucionais, evitando situações de danos ao patrimônio público federal e, principalmente, ao dinheiro arrecadado, proveniente do trabalho de milhares de brasileiros.

\section{REFERÊNCIAS}

ALVIM, Arruda. Os limites existentes ao controle jurisdicional dos atos administrativos. Revista dos Tribunais - RT, São Paulo, v. 99, p. I 52, 2000.

BARROSO, Luis Roberto. Curso de Direito Constitucional Contemporâneo. 2. ed. Saraiva, 2010.

BRASIL, Regimento Interno -TCE/TO, 2002. Disponível em: <http://www.tce.to.gov.br/sitetce/index.php?option=com_docman\&ltemid=57> Acesso em 10 de mar. 2014.

BRASIL, Constituição do Estadual do Tocantins, 1989.

BRASIL, Constituição da República Federativa do Brasil, I 988. Brasília, DF, Senado, 1988.

BRITTO, Carlos Ayres. O Regime Constitucional Dos Tribunais De Contas. In. Revista Diálogo Jurídico, v. I, $n^{0}$ 9, Salvador. 200l. Disponível em: <http://www.infopedia.pt/\$fazenda-publica> Acesso em 3 de mar. 2014. 
FAGUNDES, Miguel Seabra. O Controle dos Atos Administrativos pelo Poder Judiciário. 4. ed. Rio de Janeiro: Forense, 1967.

FAJARDO, Cláudio Marcelo Spalla. Súmula STF n 347: uma nova abordagem sobre a competência do TCU para apreciar a constitucionalidade de leis e atos normativos do Poder Público. Belo Horizonte- MG. 2007. Disponível em <http://portal2.tcu.gov.br/portal/pls/portal/docs/20540l4.PDF>, Acesso em 2/5/20| 4 .

JACOBY FERNANDES, Jorge Ulisses. Tribunais de Contas do Brasil: jurisdição e competência. 3. ed. rev. atual. e ampl. Belo Horizonte: Fórum, 2012.

MEIRELLES, Hely Lopes. Direito Administrativo Brasileiro. 34. ed. São Paulo: Malheiros, 2008.

MENDES, Gilmar Ferreira. Curso de Direito Constitucional. 6. ed. Saraiva, 20 I I .

Tribunal de contas: história, principais características e importância na proteção do patrimônio público brasileiro. Disponível e m: <http://www.ambitojuridico.com.br/site/index.php?n_link=revista_artigos_leitura\&ar tigo_id $=$ | | | 98> Acesso em 7 de abr. 2014.

MORAES, Alexandre de. Direito Constitucional. 16. ed. São Paulo: Atlas, 2004.

NOVELINO, Marcelo. Direito Constitucional. 3. ed. São Paulo: Método; Rio de Janeiro: Forense, 2009.

PAULO, Vicente; ALEXANDRINO, Marcelo. Direito Constitucional Descomplicado. 4. ed. São Paulo: Método, 2009.

ROSAS, Roberto. Direito Sumular. São Paulo - Malheiros, 2004. Disponível em $<$ http//www.stf.jus.br >. Acesso em 17 de abr. 2014.

SILVA, De Plácido e. Vocabulário Jurídico. 27. ed. Rio de Janeiro: Forense, 2006.

Recebido em: 15/02/2016

Aprovado em: 25/06/2016 